\title{
The Adaptation of Aerobacter Aerogenes to the Stress of Sublethal Doses of Formaldehyde
}

\author{
BY W. B. NEELY \\ Biochemical Research Laboratory, The Dow Chemical Company \\ Midland, Michigan, U.S.A.
}

(Received 2 November 1965)

\begin{abstract}
SUMMARY
This paper deals with some biochemical events that occur when a population of Aerobacter aerogenes is treated with a sublethal dose of formaldehyde. It was discovered that during the bacteriostatic period there was a change in the base ratio of the non-ribosomal RNA. Along with this change there was the appearance of induced enzymes capable of metabolizing the formaldehyde at an increased rate. As soon as the formaldehyde concentration had been decreased by metabolism, growth resumed and the base ratio of the RNA returned to a normal value.
\end{abstract}

\section{INTRODUCTION}

Biological systems are constantly being exposed to some form of stress from the environment in which they are located. The challenge, which may be in the form of chemical or physical agents, elicits various reactions from the organism, ranging from lethal to beneficial. These reactions are very important since biological evolution is influenced to a great extent by the organism's response to the challenge. Indeed, it may be stated that without stress there would be no evolution and without evolution there would be no life as we know it. One of the problems in studying the biochemical events associated with stress is the length of time involved in determining its effects on succeeding generations. Bacterial systems because of their short generation times overcome this difficulty. Stress may be applied at controlled periods of growth and the influence on future generations may be observed during a 24-hr period.

My work with the action of formaldehyde on Aerobacter aerogenes (Neely, 1963a, $b, c)$ led me to look on this situation as a means of elucidating some of the events by which bacteria adapt to stress. The investigations cited in the above references were concerned with gaining a better understanding of how formaldehyde exerts its antimicrobial activity. Substerilizing concentrations of ${ }^{14} \mathrm{C}[\mathrm{HCHO}$ were added to a growing culture of Aerobacter aerogenes and the rate of ${ }^{14} \mathrm{C}\left[\mathrm{CO}_{2}\right]$ evolution was measured. This work demonstrated that such concentrations of formaldehyde had an initial bactericidal action followed by a bacteriostatic period. As soon as the formaldehyde had been depleted to a certain critical concentration by metabolism; the culture resumed its normal growth pattern. By using this same system, it was the intention of the present work to gain a better understanding of how a population of microorganisms, specificaliy, $A$. aerogenes, reacts to the stress of the presence of formaldehyde. The purpose will be to correlate the biochemical events with the physiological observations. 


\section{METHODS}

Growth of organism. Aerobacter aerogenes ATCC 8308, was grown and maintained at $30^{\circ}$ as described previously (Neely, 1963 $a$ ) in the defined medium of Warren, Ells \& Campbell (1960).

Analytical techniques. The procedures for measuring growth, viability and ${ }^{14} \mathrm{C}\left[\mathrm{CO}_{2}\right]$ evolution were similar to those used in the earlier investigation (Neely, $1963 a)$. The ${ }^{14} \mathrm{C}\left[\mathrm{CO}_{2}\right]$ evolution curves are the result of a continuous recording of the ${ }^{14} \mathrm{C}$ activity as measured by a Cary Model 31 vibrating reed electrometer (Applied Physics Corp.). The ionization chamber used in this investigation had been previously calibrated (Neely, 1963a). By means of this calibration $(25.6 \mathrm{mV}$ were equivalent to $0.0458 \mu \mathrm{c}$ ) the activity of the $\mathrm{CO}_{2}$ evolved could be determined from the area under the curve. In all cases reported in this investigation, the amount of formaldehyde metabolized was in the range from 87 to $90 \%$. In the metabolism experiment, a modification was made to allow periodic sampling $(0.2 \mathrm{ml}$. samples $)$ of the culture for making colony counts. A hypodermic needle was inserted into the air inlet hose next to the Warburg flask. A length of tubing was attached to the needle to reach the bottom of the flask which contained the culture. In this manner the viability and rate of ${ }^{14} \mathrm{C}\left[\mathrm{CO}_{2}\right]$ evolution were measured on the same culture.

Chemicals. The ${ }^{14} \mathrm{C}$-labelled formaldehyde (specific activity of $10 \mathrm{mc} / \mathrm{m}$-mole) was supplied by the New England Nuclear Corporation (Boston, Massachusetts, U.S.A.) Parke-Davis Co., (Detroit, Michigan, U.S.A.) brand of chloramphenicol was used in the investigation. All other chemicals were of reagent grade.

$R N A$ base composition. The cultures were grown aerobically with and without formaldehyde $(50 \mu \mathrm{g} . / \mathrm{ml}$.) in 5-1. volumes with constant agitation to ensure maximum growth. The formaldehyde was added to the culture at the beginning of the exponential growth phase. Samples (1000 ml.) were removed as indicated in Table 1 and the bacteria were centrifuged down, and washed with $0.9 \% \mathrm{NaCl}$ solution. The sample for the resting culture (Table 1 ) was obtained by centrifuging $1000 \mathrm{ml}$. of culture which had just reached exponential growth, these bacteria were washed in $0.9 \% \mathrm{NaCl}$ solution, re-suspended in $\mathbf{0 . 2} \%$ glucose solution, maintained for $7 \mathrm{hr}$ at room temperature and then were recentrifuged.

Total RNA was purified by a modification of the method of Volkin \& Astrachan (1956). The centrifuged bacteria were placed in the Omni Mixer (Ivan Sorvall, Inc., Norwalk, Conn.) with an equal weight of glass beads and water. The mixture was chilled and disrupted for $15 \mathrm{~min}$. centrifuged at $14,000 \mathrm{~g}$ for $15 \mathrm{~min}$. and the supernatant fluid extracted with an equal volume of a chloroform +isoamylalcohol mixture $(20+1$ by vol.). The liquid layers were separated and the top (aqueous) layer re-extracted. To this aqueous layer was then added $\mathbf{1 . 5}$ volumes of ethanol and the mixture allowed to stand in the refrigerator for $1 \mathrm{hr}$. The precipitated RNA was centrifuged and dissolved in $\mathrm{N}-\mathrm{KOH}$ and allowed to hydrolyse at $37^{\circ}$ for $16 \mathrm{hr}$. Sufficient $71 \%(\mathrm{v} / \mathrm{v})$ perchloric acid was then added to bring the concentration to $0.55 \mathrm{~N}$ after neutralization of the $\mathrm{KOH}$. After $45 \mathrm{~min}$. in the cold, the solution was centrifuged, the supernatant fluid adjusted to $\mathrm{pH} 8 \cdot 0$ with ammonium hydroxide and the nucleotides resolved by ion-exchange chromatography, as described later.

Ribosomal RNA was prepared according to the method outlined by Roberts, Britten \& McCarthy (1963). The bacteria cells were chilled and disrupted for $15 \mathrm{~min}$. 
by using an ultrasonic generator (the Narda Ultrasonics Corp., Westbury, L. I., New York). The ribosomal pellet resulting from two centrifugations in the Beckman Spinco Ultracentrifuge at $92000 \mathrm{~g}$ was dissolved in $\mathrm{N}-\mathrm{KOH}$ and the hydrolysis procedure as described above was done, before chromatographic analysis.

The nucleotide mixtures were resolved on Dowex 1 ion exchange resin in the chloride from ( $2 \%$ cross-linked; 200-400 mesh) using a $20 \mathrm{~cm} . \times 1 \mathrm{~cm}$. column. The procedure was essentially that described by Gallant \& Suskin (1962). The fractions were collected by using the Vanguard Fraction Collector equipped with an automatic ultraviolet analyser for scanning the eluate at $260 \mathrm{~m} \mu$ (see Fig. 1 for a typical resolution). The tubes representing each nucleotide were pooled and examined spectrophotometrically. The final concentration was determined from the published extinction coefficients (Beaven, Holiday \& Johnson, 1955).

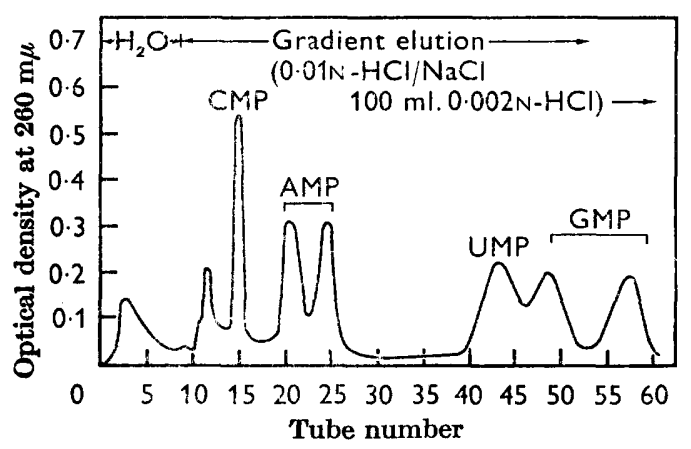

Fig. 1

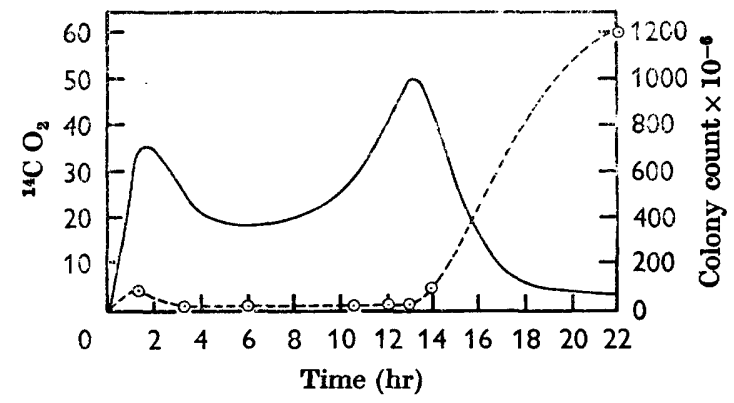

Fig. 2

Fig. 1. Chromatogram of RNA nucleotides isolated from Aerobacter aerogenes. Fractions (5 ml./tube) were eluted as shown from a $20 \mathrm{~cm} . \times 1 \mathrm{~cm}$. column at a flow rate of $1 \mathrm{ml} . /$ min. The peak appearing before the cytidylic acid has not been identified.

Fig. 2. ${ }^{14} \mathrm{C} \mathrm{O}_{2}$ evolution by Aerobacter aerogenes treated with labelled formaldehyde $(0.5 \mu \mathrm{c} / 4 \mathrm{ml}$.) at a concentration of $50 \mu \mathrm{g}$. $/ \mathrm{ml}$. The corresponding colony count (equiv. no. organisms $/ \mathrm{ml}$. culture) of the culture is shown by the broken curve. In Fig. 2, 3 and 4,10 units on the ${ }^{14} \mathrm{C} \mathrm{O}_{2}$ ordinate are equivalent to $3 \mathrm{mV}(25.6 \mathrm{mV}=0.0458 \mu \mathrm{c})$.

\section{RESULTS}

Demonstration of increased metabolic capacity for formaldehyde

To a culture of Aerobacter aerogenes which had reached the exponential growth phase, sufficient ${ }^{14} \mathrm{C}-\mathrm{HCHO}$ was added to give a final concentration of $50 \mu \mathrm{g} . / \mathrm{ml}$. and a total radioactivity of $0.5 \mu \mathrm{c}$. Periodically, $0.2 \mathrm{ml}$. samples were removed and the appropriate dilutions were made for colony counts. The results of plotting the colony count (equiv. no. organisms/ml. culture) and the evolution of ${ }^{14} \mathrm{C}-\mathrm{CO}_{2}$ against time are shown in Fig. 2. The initial burst of $\mathrm{CO}_{2}$ evolution followed by the decline to a constant rate is parallel with the viable count measurement. The second burst of $\mathrm{CO}_{2}$, however, preceded the increase in viable count by $5 \mathrm{hr}$. To a duplicate of the culture illustrated in Fig. 2 a second portion of formaldehyde (equal to the first) was added $8 \mathrm{hr}$ after the first addition. This time period was chosen because it coincided with an increase in the rate of ${ }^{14} \mathrm{C}-\mathrm{CO}_{2}$ evolution and it was before any change in the viable count. No detectable lag in the ${ }^{14} \mathrm{C}-\mathrm{CO}_{2}$ evolution was noted as a result of this 
second addition of formaldehyde (Fig. 3). By measuring the area under the ${ }^{14} \mathrm{C}-\mathrm{CO}_{2}$ curves in Figs. 2 and 3 it was calculated that the area in Fig. 3 was twice that of Fig. 2. Finally, to help exclude strain selection as opposed to induction of formaldehyde-metabolizing enzymes the following experiment was performed. A culture which had been exposed to formaldehyde $50 \mu \mathrm{g} . / \mathrm{ml}$. was allowed to recover (Fig. $2 ; 22 \mathrm{hr}$ ); this culture was then used as a source of inoculum for a repeat of the experiment shown in Fig. 2. No difference in the pattern of ${ }^{14} \mathrm{C}-\mathrm{CO}_{2}$ evolution or viable count was noted.

\section{The action of chloramphenicol}

To culture which had reached the exponential phase of growth (similar to the previous experiments) ${ }^{14} \mathrm{C}-\mathrm{HCO}(0.5 \mu \mathrm{c} ; 50 \mu \mathrm{g}$. $/ \mathrm{ml}$. culture) was added. At subsequent time intervals, chloramphenicol was added to a final concentration of

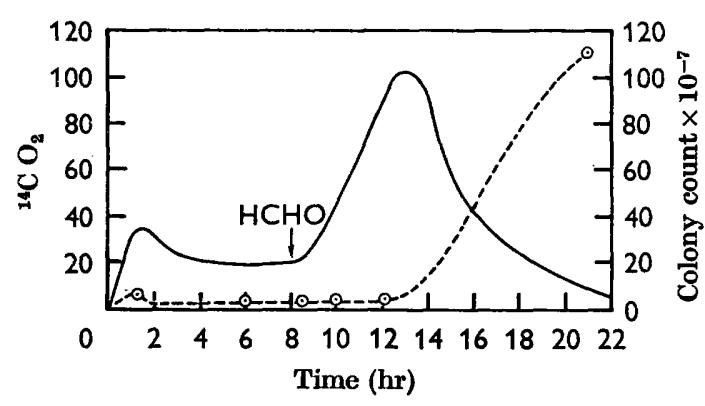

Fig. 3

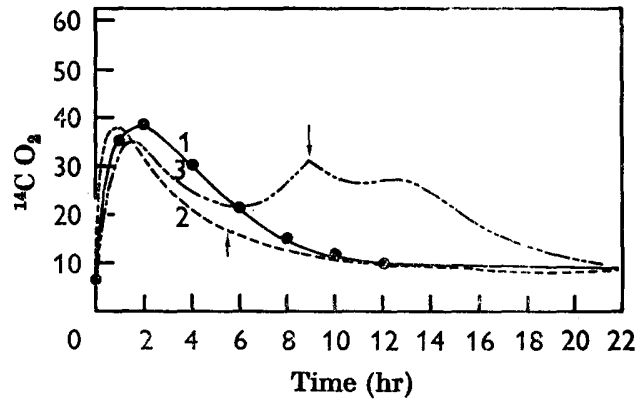

Fig. 4

Fig. 3. ${ }^{14} \mathrm{C}-\mathrm{CO}_{2}$ evolution by Aerobacter aerogenes treated with labelled formaldehyde at $0 \mathrm{hr}$. and at $8 \mathrm{hr}$. Each portion was equivalent to $0.5 \mu \mathrm{c} / 4 \mathrm{ml}$. at a concentration of $50 \mu \mathrm{g} . / \mathrm{ml}$. The corresponding colony count (equiv. no organisms $/ \mathrm{ml}$. culture) is shown by the broken curve.

Fig. 4. ${ }^{14} \mathrm{C} \mathrm{O}_{2}$ evolution by Aerobacter aerogenes treated with labelled formaldehyde $0.5 \mu \mathrm{c} / \mathrm{ml}$.) at a concentration of $50 \mu \mathrm{g} . / \mathrm{ml}$. Curve 1, chloramphenicol $25 \mu \mathrm{g} . / \mathrm{ml}$. added at $0 \mathrm{hr}$; Curve 2, chloramphenicol $25 \mu \mathrm{g} . / \mathrm{ml}$. added at $5.5 \mathrm{hr}$; curve 3, chloramphenicol $25 \mu \mathrm{g} . / \mathrm{ml}$. added at $9 \mathrm{hr}$.

$25 \mu \mathrm{g} . / \mathrm{ml}$. The results of these experiments are shown in Fig. 4. The curves are quite dramatic and indicate that the second large burst of $\mathrm{CO}_{2}$ was prevented by the presence of the antibiotic. Curve 3 is noteworthy since in this case the chloramphenicol was added after the ${ }^{14} \mathrm{C}-\mathrm{CO}_{2}$ evolution had indicated an increase in rate.

\section{Base ratio analysis}

The base ratio analyses for the total RNA and ribosomal RNA for the normal culture were independent of the time of isolation. The data in Table 1 are in close agreement with those reported for Aerobacter aerogenes by Midgley (1962). The striking result in Table 1 is the base ratio for the total RNA from a culture that was under the stress of formaldehyde treatment. An analysis of variance of the data in Table 1 showed a significant decrease in the amount of cytidylic acid and a significant increase in the amount of uridylic acid, as compared to the normal ratio. This analysis is reported in Table 2. All other samples of RNA including the RNA isolated 
Table 1. Base composition of total and ribosomal RNA of Aerobacter aerogenes synthesized in the presence and absence of formaldehyde

Sample $\quad \overbrace{\text { Cytidylate Uridylate }}^{\text {Moles } \% \text { of: }}$ Adenylate Guanylate* $_{\text {Ade }}^{\text {Gen }}$

Culture grown in absence of formaldehyde

(a) Beginning of log growth

Total RNA $\dagger$

Ribosomal RNA

(b) Resting culture

Total RNA

(c) 24-hr culture

Total RNA $\dagger$

Ribosomal RNA

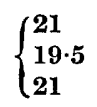

$\left\{\begin{array}{l}20 \cdot 5 \\ 19 \cdot 5\end{array}\right.$

$\{20$

$\{20 \cdot 5$
22
24
23

$\mathbf{2 3 \cdot 5}$

$24 \cdot 5$

24

$23 \cdot 5$
26

25.5

$26 \cdot 5$

$25 \cdot 5$

26

25

$25 \cdot 5$

24

$23 \cdot 4$

$23 \cdot 7$

23

$23 \cdot 5$

\section{4}

\section{6}

25

25

$\left\{\begin{array}{l}19 \cdot 5 \\ 19.5\end{array}\right.$

30

31

$30 \cdot 5$

$30 \cdot 5$

30

$30 \cdot 5$

31

Culture grown in presence of formaldehyde

(a) $7 \mathrm{hr}$ after addition of formaldehyde (see Fig. 2)

\begin{tabular}{|c|c|c|c|c|}
\hline Total RNA $\dagger$ & $\left\{\begin{array}{l}17 \cdot 5 \\
18 \\
18\end{array}\right.$ & $\begin{array}{l}25 \cdot 5 \\
25 \cdot 5 \\
26\end{array}$ & $\begin{array}{l}26 \\
26 \cdot 5 \\
26\end{array}$ & $\begin{array}{l}31 \cdot 5 \\
30 \\
30\end{array}$ \\
\hline Ribosomal RNA & $\left\{\begin{array}{l}21 \\
20\end{array}\right.$ & $\begin{array}{l}23 \\
23 \cdot 5\end{array}$ & $\begin{array}{l}26 \cdot 5 \\
26\end{array}$ & $\begin{array}{l}29 \cdot 5 \\
30 \cdot 5\end{array}$ \\
\hline
\end{tabular}

(b) $24 \mathrm{hr}$ after addition of formaldehyde

\begin{tabular}{|c|c|c|c|c|}
\hline Total RNA $\dagger$ & $\left\{\begin{array}{l}21 \\
19 \cdot 5 \\
21\end{array}\right.$ & $\begin{array}{l}22 \cdot 5 \\
23 \\
23 \cdot 5\end{array}$ & $\begin{array}{l}26 \\
25 \cdot 5 \\
26\end{array}$ & $\begin{array}{l}30 \cdot 5 \\
31 \\
29 \cdot 5\end{array}$ \\
\hline
\end{tabular}

* Each horizontal row represents an individual experiment on a separate culture of $A$. aerogenes.

$\dagger$ These results were used for the analysis of variance shown in Table 2.

Table 2. Analysis of variance of the data shown in Table 1. The analysis was made on the results for cytidylic and uridylic acid

$\begin{array}{lccc}\begin{array}{l}\text { Source of variation } \\ \text { 1. Age level of culture }\end{array} & \begin{array}{c}\text { Degrees of } \\ \text { freedom }\end{array} & \begin{array}{c}\text { Average } \\ \text { variance }\end{array} & \begin{array}{c}\text { Variance } \\ \text { ratio* }\end{array} \\ \begin{array}{l}\text { 2. With and without } \\ \text { formaldehyde }\end{array} & 1 & 0 \cdot 04 & \\ \text { 3. Nucleotide } & 1 & 0 \cdot 04 & \\ \text { Interactions } & 1 & 100 \cdot 86 & 219 \cdot 3 \\ 1 \times 2 & & & \\ 1 \times 3 & 1 & 0 \cdot 05 & \\ 2 \times 3 & 1 & 6 \cdot 83 & 14 \cdot 8 \\ 1 \times 2 \times 3 & 1 & 6 \cdot 83 & 14 \cdot 8 \\ \text { Replicates } & 1 & 15 \cdot 35 & \mathbf{3 3 \cdot 4} \\ & 16 & 0 \cdot 46 & \end{array}$

* Significant at 0.01 probability level. 
from the 7 -hr static culture and the ribosomal RNA from the formaldehyde-treated culture were similar to the base ratio found for the untreated population.

\section{DISCUSSION}

The experiment shown in Fig. 2 indicates that the increase in the rate of metabolism of formaldehyde ( $8 \mathrm{hr}$ after addition of $\mathrm{HCHO}$ ) was due to the increased ability of Aerobacter aerogenes to convert $\mathrm{HCHO}$ to $\mathrm{CO}_{2}$. This conclusion is established by the fact that during the increase in rate of $\mathrm{CO}_{2}$ evolution the concentration of viable organisms in the culture was constant. Normal growth as judged by increase in colony count occurred only when most of the HCHO had been removed. The initial burst of ${ }^{14} \mathrm{C}-\mathrm{CO}_{2}$ followed by a decline to a steady state may be correlated with the decrease in colony count. Fig. 2 indicates that the rate of ${ }^{14} \mathrm{C}-\mathrm{CO}_{2}$ evolution decreased from a high value of $36 \mathrm{mV}$ to $18 \mathrm{mV}$; during this interval there was a corresponding decrease in the colony count. These results suggest that induced enzymes might be responsible for the second large burst of $\mathrm{CO}_{2}$. If induced enzymes were not responsible for the observed increase in rate of ${ }^{14} \mathrm{C}-\mathrm{CO}_{2}$ evolution then a second addition of $\mathrm{HCHO}$ at $8 \mathrm{hr}$ in Fig. 3 should prolong the lag. This did not occur; the second portion of $\mathrm{HCHO}$ was metabolized at an increasing rate even though the colony count was constant. A possible explanation for this observation is that the initial HCHO had caused the induction of the necessary enzymes; consequently the culture was able to metabolize the second quantity of HCHO without the usual lag period. An alternative explanation might be that a small fraction of the bacteria population was capable of metabolizing $\mathrm{HCHO}$ and then to grow in its presence. If this were the case, then two events should have occurred. (1) the increase in the rate of ${ }^{14} \mathrm{C}-\mathrm{CO}_{2}$ evolution at $8 \mathrm{hr}$ should have coincided with an increase in the population; (2) an inoculum resulting from a population that had been exposed to HCHO and allowed to recover, i.e. a 24-hr culture should have shown no lag. Neither of these results occurred, thus lending further support to the thesis that the increase in the capacity of the organisms to handle $\mathrm{HCHO}$ was due to an increase in the concentration of HCHO-metabolizing enzymes.

Since chloramphenicol has been shown to be an inhibitor of protein synthesis (Hunter, Brookes, Crathorn \& Bolter, 1959), and of inducible enzyme formation (Mandelstam, 1957; Pollock \& Kramer, 1958; Eisenstadt \& Klein, 1961), the experiments with this compound demonstrated that de novo synthesis of new protein was required for the metabolism of HCHO. Curve 3 in Fig. 4 shows that the lag in appearance of increased metabolic activity must be due to the time involved for non-dividing cells to mobilize the means necessary to cause the synthesis of the necessary proteins. It has been previously shown (Neely, 1963c) that HCHO during this bacteriostatic period is an inhibitor of cytoplasmic and nuclear syntheses which are necessary for new growth. However, during this lag there is a continual low degree of metabolism of $\mathrm{HCHO}$, consequently, a point is reached where the inhibition is removed to such an extent as to allow the synthesis of new protein. One of the first proteins to be made must be the system for metabolizing HCHO at an increased rate, thus allowing the culture to return to its normal physiological state.

The base ratio analysis would imply that the $\mathrm{HCHO}$ caused a change in the nonribosomal RNA. This result comes from the observation that no change in the base 
ratio of the ribosomal RNA was detected; however, there was a significant change in the cytidylic and uridylic acid in the total RNA from the HCHO treatment. Once the culture had depleted the HCHO and normal growth had resumed, the base ratio of the RNA also returned to normal. This evidence suggests that the change in ratio might be related to the appearance of enzymes responsible for the increased metabolism of $\mathrm{HCHO}$. At the concentrations used $\mathrm{HCHO}$ was bacteriostatic. The possibility existed, therefore, that the altered base ratio in the RNA was merely due to the physiological state of bacteriostasis and was not related directly to the metabolism of HCHO. Since there was no change in the RNA as a result of the prolonged period of bacteriostasis (see results for resting bacteria in Table 1) this possibility seems excluded.

Another observation from the analysis of variance in Table 2 is that the decrease in cytidylic acid was exactly compensated by an increase in uridylic acid. It is interesting to speculate on the possibility that HCHO prevents the conversion of uridine to cytidine and in this manner causes the observed alteration in the base ratio.

The following items are presented as the sequence of events which enable a population of Aerobacter aerogenes to adapt and recover from a sublethal dose of formaldehyde. 1. A certain number of bacteria are killed as indicated by the initial decrease in colony count (Neely, $1963 a$ ). 2 . The loss in viability is neutralized by the reaction between formaldehyde and homocysteine to form 1,3-thiazane-4-carboxylic acid (Neely, 1963b). This reaction blocks methionine biosynthesis and successfully counteracts the potential death from unbalanced growth (Neely, 1963c). 3. As the present work indicates, during this static period of growth the physiology of the population is altered in the direction of an increased potential for metabolizing formaldehyde. This potential is expressed as soon as the static culture has decreased the formaldehyde concentration to the point where new protein synthesis can occur.

\section{REFERENCES}

Beaven, G. H., Holiday, E. R. \& Johnson, E. A. (1955). Optical properties of nucleic acids and their components. The Nucleic Acids, New York: Academic Press, p. 513.

Eisenstadt, J. M. \& KLein, H. P. (1961). Evidence for the de novo synthesis of the alpha amylase of Pseudomonas saccharophilia. J. Bact. 82, 798.

Gallant, J. \& Suskin, S. R. (1962). Ribonucleic acid synthesis and thymineless death. Biochim. biophys. Acta 55, 627.

Hunter, G. D., Brookes, P., Crathorn, A. R. \& Bolter, J. A. V. (1959). Intermediate reactions in protein synthesis by the isolated cytoplasmic membrane fraction of Bacillus megaterium. Biochem. J. 73, 369.

MANDELSTAM, J. (1957). Turnover of protein in starved bacteria and its relationship to the induced synthesis of enzyme. Nature, Lond. 179, 1179.

MidGLEY, J. E. (1962). The nucleotide base composition of ribonucleic acid from several microbial species. Biochim. biophys. Acta 61, 513.

NeELy, W. B. (1963a). Action of formaldehyde on microorganisms. 1. Correlation of activity with formaldehyde metabolism. J. Bact. 85, 1028.

NeeLy, W. B. $(1963 b)$. Action of formaldehyde on microorganisms. II. The formation of 1,3-thiazone-4-carboxylic acid in Aerobacter aerogenes. $J$. Bact. 85, 1420.

NEELY, W. B. (1963c). Action of formaldehyde on microorganisms. III. Bactericidal activity of formaldehyde in sublethal concentrations. J. Bact. 86, 445.

Pollock, M. R. \& Kramer, M. (1958). Intermediates in the biosynthesis of bacterial penicillinase. Biochem. J., 70, 665. 
Roberts, R. B., Britren, R. J. \& McCarthy, B. J. (1963). Kinetic studies on the synthesis of RNA and ribosomes. Molecular Genetics Pt. 1, p. 291. New York: Academic Press.

Volkin, E. \& Astrachan, L. (1956). Phosphorus incorporation in Escherichia coli ribonucleic acid after infection with bacteriophage +2 . Virology 2, 149.

Warren, R. A. J., Ells, A. F. \& Campbell, J. J. R. (1960). Endogenous respiration of Pseudomonas aeruginosa. J. Bact. 79, 875. 